Implementing European Case Law at the Bureaucratic Frontline How Domestic Signalling Influences the Outcomes of EU Law

Martinsen, Dorte Sindbjerg; Blauberger, Michael; Heindlmaier, Anita; Thierry, Jessica Maria Sampson

Published in:

Public Administration

DOI:

10.1111/padm.12603

Publication date:

2019

Document version

Peer reviewed version

Citation for published version (APA):

Martinsen, D. S., Blauberger, M., Heindlmaier, A., \& Thierry, J. M. S. (2019). Implementing European Case Law at the Bureaucratic Frontline: How Domestic Signalling Influences the Outcomes of EU Law. Public Administration, 97(4), 814-828. https://doi.org/10.1111/padm.12603 


\title{
Implementing European Case Law at the Bureaucratic Frontline: How Domestic Signalling Influences the Outcomes of EU Law
}

\author{
Dorte Sindbjerg Martinsen, University of Copenhagen, dm@ifs.ku.dk \\ Michael Blauberger, University of Salzburg, michael.blauberger@sbg.ac.at \\ Anita Heindlmaier, University of Salzburg, anita.heindlmaier@sbg.ac.at \\ Jessica Sampson Thierry, University of Copenhagen, jimst@ifs.ku.dk
}

Pre-print version as accepted in

Public Administration

https://onlinelibrary.wiley.com/doi/abs/10.1111/padm.12603

\begin{abstract}
This article analyses the implementation of European case law at the bureaucratic frontline of European Member States. Theoretically, insights from street-level implementation studies are combined with judicial impact research. Empirically, we compare how EU rules on free movement and cross-border welfare are applied in practice in Denmark, Austria and France. We find that when applying EU rules in practice, street-level bureaucrats are confronted with a world of legal complexity, consisting of ambiguous rules, underspecified concepts and a recent judicial turn by the Court of Justice of the European Union (CJEU). In order to manage complexity, street-level bureaucrats turn to their more immediate superiors for guidance. As a consequence, domestic signals shape the practical application of EU law. Despite bureaucratic discretion and many country differences, domestic signals create uniform, restrictive outcomes of EU law in all three cases We, thus, show that there is considerable room for politics communicated by means of domestic signalling - in the EU implementation processes.
\end{abstract}

\section{KEYWORDS}

Free movement of workers, welfare benefits, Court of Justice of the European Union (CJEU), implementation, domestic signalling, bureaucratic frontline, street-level bureaucracy 


\section{INTRODUCTION}

Free movement and equal treatment of European Union (EU) citizens are among the core principles of European integration. If any further proof was needed, the Brexit referendum and its aftermath have demonstrated how politically salient these principles can become. However, despite their central role in European integration, little is known about their application in practice and how the bureaucratic frontline ultimately decides on the scope and limits of these rules.

The bureaucratic frontline consists of street level bureaucrats (SLBs) handling the dayto-day implementation of EU rules and rights. They are confronted with EU-related challenges. Firstly, the distance from abstract EU principles and rules to their street-level application is immense and involves many potential mitigating and diverting factors. Secondly, core EU policies such as free movement are often shaped by the jurisprudence of the Court of Justice of the European Union (CJEU). Hence, implementation is not limited to 'once and for all' legislative transposition, but requires a continuous absorption of the Court's evolving case law. And due to the case specific character of CJEU rulings, general policy formulations are difficult to derive. Such implementation challenges resemble what confront SLBs in federal states as well as in states with strong constitutional courts. As such EU challenges are not unique. However, the EU system adds an extra layer of complexity, likely to affect how SLBs attend to supranational rules.

In this paper, we examine how SLBs in Denmark, Austria and France apply EU rules in practice. To do so, we combine insights from the literature on policy implementation (Lipsky, 1980) with literature on judicial impact (Canon, 1991; Conant, 2002). These two strings of literature are likely to inform us of what shapes bureaucratic decisions at the street level when applying EU law in practice. In line with these literatures, we examine how ambiguous legal principles and case law influence decision-making at the bureaucratic frontline. When implementing EU rules on free movement and equal treatment, SLBs are confronted with a world of legal complexity and underspecified concepts stemming from both EU legislation and the jurisprudence of the CJEU. Two rather different expectations on how SLBs deal with this discretion arise from this. On the one hand, practical implementers are likely to employ a variety of coping strategies and to be influenced by individual motivations. Accordingly, one might expect to find considerable variation in the decision-making of SLBs. Variation can be caused by EU legal ambiguity, since the three selected country cases differ on key parameters but also by SLBs' individual motivations in case-handling. On the other hand, we develop an alternative expectation. Domestic signalling from the superiors of SLBs may guide their behaviour, leading to a more uniform application of EU rules and rights on the ground. Uniform application can be the outcome, as signalling denotes the importance and content assigned to a policy from the superior. The two expectations thus contrast on how European rules play out on the ground.

The paper is structured as follows. Section two brings together two distinct literatures on respectively street-level implementation and judicial impact. They inform the two theoretical expectations on discretion and control of frontline bureaucrats in the EU. Section three presents the legal framework on free movement and equal treatment. In section four, we compare three country cases - Denmark, Austria and France - which differ in numerous respects both within and across countries, but exhibit striking similarities in terms of the outcomes that result from frontline application of European case law. Section five concludes.

\section{STREET-LEVEL IMPLEMENTATION AND JUDICIAL IMPACT}

EU implementation studies have recently taken a new turn, exploring and explaining how EU legislation and jurisprudence are applied in practice (Blauberger, 2013; Falkner, Treib, Hartlapp, \& Leiber, 2005; Hofmann, 2018; Thomann \& Sager, 2017b; Versluis, 2007a; 
Zhelyazkova, Kaya, \& Schrama, 2016). Among other puzzles, the emerging literature investigates the outcomes of rather complex EU legislation, when implemented on the ground and their variation across national institutions, different administrative traditions as well as different compliance cultures.

On the one hand, implementation studies lead us to expect varying outcomes of EU rules. The high level of legal ambiguity in EU rules enhances administrative discretion. One of the pioneering implementation researchers emphasised the role of conflict and found it to continue from policy formulation, through decision-making into policy implementation (Bardach, 1977). One reason is that conflicts about policy formulation often result in policies marked by ambiguous goals and rules (Winter, 2012, p. 258). Ambiguous compromises may facilitate agreement in the first place, but they complicate matters at later stages of implementation, delaying transposition (Steunenberg \& Toshkov, 2009) and allowing for discretionary rule application. Apart from a great variety of country-level factors accounting for differentiated Europeanization (Treib, 2014), EU implementation scholars recently started to explore how ambiguity affects the application of European law at the individual level of frontline bureaucrats. Drawing on insights from social psychology, Dörrenbacher finds that in contexts of high legal ambiguity, street-level bureaucrats' individual motivation influences their use of EU law (Dörrenbächer, 2017). As a result, the extent to which the frontline bureaucracy relies on EU law varies and produces different administrative decisions. EU law delegates discretion to practical implementers, 'who thus become, in essence, EU lawmakers' (Dörrenbächer \& Mastenbroek, 2017). Implementers are creative and flexible when using legal tools, which leads to variation in implementation practices.

In a similar vein, judicial impact studies have shown that unclear jurisprudence lends itself to discretionary application on the ground - either accidentally, simply by leaving implementers uncertain about judges' intent, or intentionally, by providing leeway for application in line with the implementers' own preferences (Baum, 1976, p. 92). Moreover, based upon this literature, we should expect policies that are strongly shaped by jurisprudence to exhibit particularly high degrees of legal ambiguity. Individual judgments often create additional legal ambiguity as to their broader implications (Baum, 1976, p. 93). In contrast to legislation, jurisprudence is always case-specific and fragmented. Moreover, high courts face a particular dilemma of providing guidance without constraining too much their own flexibility to respond to future developments. Any obvious deviation or even turnaround of established precedent would only increase legal ambiguity and, hence, the likelihood of varied implementation. In the EU context, CJEU rulings often include broad interpretative guidelines, but leave considerable discretion for their domestic application, a strategy which is seen as crucial to ensure national courts' loyalty (Davies, 2012, p. 88). For frontline bureaucrats, however, trying to handle mass proceedings efficiently and predictably, discretion often appears as a curse rather than a blessing (Blauberger \& Schmidt, 2017, p. 4).

Faced with legal ambiguity, frontline bureaucrats typically employ a broad variety of coping strategies. Their basic dilemma is one of using discretion in order to account for the individual situations of their clients, while managing mass proceedings efficiently and predictably (Lipsky, 1980, p. 18). Building on Lipsky, coping has been defined as the 'behavioral efforts frontline workers employ when interacting with clients, in order to master, tolerate, or reduce external and internal demands and conflicts they face on an everyday basis' (Tummers, Bekkers, Vink, \& Musheno, 2015, p. 1100). A great diversity of such coping strategies has been identified and classified. Tummers et al. broadly distinguish between coping strategies benefitting the frontline worker - such as routinizing and rationing the treatment of clients instead of conducting individual assessments - and those coping strategies serving the clients' interests - for example the bending or breaking of rules to meet client demands or the prioritizing of some clients (2015, p. 1108). 
On the other hand, domestic signalling may direct frontline bureaucrats to a specific interpretation of EU law. Signalling denotes how superiors communicate or interpret the importance and content of a policy (May \& Winter, 2009, p. 454). Via signalling principals or superiors can indicate their interpretation of, interest in and the importance they assign to a policy matter. Signalling may thus mitigate distances between the preferences of a principal and its agent, reduce the agent's discretion when applying a policy (Banks \& Weingast, 1992) and steer bureaucratic responses in a specific direction (Brehm \& Gates, 1999). However, signalling should not be mistaken for continuous hierarchical control or top-down interference with street-level decisions. It is unlikely to steer specific case handling directly, but instead conveys how the superior would prioritise or decide in a similar case or situation. Signalling may thus be especially effective when a case is unclear and in need of external advice or direction.

The signalling approach suggests that bureaucratic routines and decision-making are influenced by issue salience (Worsham \& Gatrell, 2005). Issue salience implies that a topic has high visibility and importance (Versluis, 2007a). High issue salience may be stable and established bureaucratic routines will prioritise the matter. At other times, salience increases, leading to intensified signals and changes in bureaucratic routines. Here superiors come to assign an increasing salience to a specific policy. Changes in government or important shifts in public opinion are among the background factors, which may explain why new signals emerge or intensify.

In an EU context, signalling can in principle come from supranational as well as national superiors. It can take several venues and may differ according to the sender. However, implementation scholars note that SLBs are more likely to be influenced by the signals of more immediate superiors, hence actors at the domestic level (May \& Winter, 2009). But also at the domestic level, superiors may send different signals. Thus in a multilevel system as the EU, multiple superiors may signal differently, communicating contradictory interests and understandings of the same policy (Worsham \& Gatrell, 2005). So far implementation theory has mainly assigned importance to signals stemming from the political or managerial level. However, in the EU as well as in other political systems with a strong judiciary, also signals from courts are likely to influence bureaucratic case-handling. Thus in our combined framework, domestic signals may come from political, administrative or judicial superiors. Political superiors, that is elected decision-makers, signal their policy preferences through many channels such as public statements, legislation, proposals for legislative reform or interventions in courts. Administrative superiors, that is civil servants in the responsible ministry, agency, at the regional or local level, signal by means of executive orders, guidelines, organisation of training seminars or regular monitoring of frontline decisions. Judicial superiors, that is domestic courts or quasi-judicial bodies, signal their interpretation of EU legal principles in the way and extent to which they apply CJEU doctrine to the facts of individual cases.

By their wording of an EU policy or their interpretation of EU law, superiors communicate 1) the importance they assign to a supranational rule as for example the importance of equal access for EU citizens to welfare benefits and they 2) give direction to how the content of a policy should be interpreted, for example whether underspecified concepts or ambiguous EU law should be interpreted restrictively or expansively. Substantive domestic signals may push frontline bureaucrats to use their room for interpretation in a certain direction as for example towards a more restrictive interpretation of EU law. The effect will be stronger if different superiors signal in the same direction. Consensus on how to read a law may gradually emerge when different superiors communicate and interact. When political superiors communicate their understandings of a policy, the administrative superior is likely to take these signals on board when communicating legislative objective further down the chain of implementation. Also when it comes to the judicial branch, positive reactions by government 
officials and favourable commentary by opinion leaders are expected to strengthen judicial impact (Levine, 1970, p. 591). By contrast, the more uniformly implementers disagree with a specific line of judicial reasoning, the more likely they are to obstruct broader judicial impact (Canon, 1991, p. 444). Accordingly, courts are understood as potential 'catalyst(s) of change rather than a singular effector of change' in this literature (Levine, 1970, p. 592). Thus, also when it comes to courts, domestic signalling may influence the assessment of individual cases.

In sum, legal ambiguity and signalling lead to different expectations regarding the behaviour and decisions of SLBs. From a perspective focusing on SLBs' coping with legal ambiguity, we should therefore expect that the outcomes of frontline bureaucrats' decisionmaking differ greatly between and within our three country cases. Yet, when considering the implications of domestic signalling, we should expect that the outcomes of frontline bureaucrats' decision-making could converge if signalling guides SLBs in the same direction.

\section{FREE MOVEMENT OF PERSONS AND CROSS-BORDER WELFARE: AMBIGUOUS RULES, LEGAL UNCERTAINTY}

The rules that govern EU citizens' right to free movement and cross-border welfare consist of primary law, secondary legislation and a considerable complex of CJEU decisions. Article 45 of the Treaty lays down that workers in the European Union have freedom of movement and cannot be discriminated against based on nationality. The Treaty's article 48 adds that in order to facilitate freedom of movement, the worker has the right to access the social security schemes of other Member States and to export previously earned social security rights.

In order to realise these Treaty objectives, the European Community adopted some of its first regulations within the field. Regulation 883/2004, grants access to and exportability of a wide range of social security benefits for EU citizens and their family members, including health care; maternity and equivalent paternity benefits; old-age benefits; unemployment benefits, and family benefits, but not social assistance. In addition, regulation 492/2011 covers workers as well as their family members who have access to all social advantages in a host member state including social assistance and study grants. However, in general, these social advantages cannot be exported. Finally, in terms of secondary legislation, the Residence Directive 2004/38 lays down that every EU citizen has the right to reside on the territory of another EU country the first three months with no conditions other than holding a valid identity card or passport. Residence for more than three months is subject to certain conditions, which vary depending on the citizen's status. Workers and self-employed and their direct family members have the right to reside without any conditions. Jobseekers have the right to reside without any conditions for a period of six months and even longer, if they continue to have a 'genuine chance' of getting work. Economically inactive persons (e.g. unemployed, retired, etc.) have the right to reside for longer than three months if they have health insurance and 'sufficient resources' for themselves and their family not to become a burden on the hosting member state's social assistance system. Sufficient resources, for their part, may not be defined as a fixed amount, and may in any case not be higher than the threshold for social assistance. Rather, Member States need to consider the individual situation of the person (Art. 8 (4) Directive 2004/38).

In many proceedings before the Court, the CJEU has been asked to clarify the social rights of EU citizens. Concerning the concept of worker, the Court has broadened its definition to also include persons with low income and part-time work. In the case of $\operatorname{Kempf}(\mathrm{C}-139 / 85)$, the CJEU established that working 12 hours per week would suffice, and in the case of Megner and Scheffel (C-444/93), it ruled that 10 hours of work per week did not exclude a person from obtaining worker status. In Ninni-Orasche (C-413/01), the CJEU stated that a fixed-term contract for ten weeks was sufficient to be a worker under EU law. However, at the same time, the expansive judicial interpretations have not been codified into secondary legislation by the 
EU legislature (Martinsen, 2015). It remains up to the member states to interpret the worker concept in concrete case-handling, thus leaving more leeway for discretion in practical implementation.

When it comes to the social rights of economically inactive EU citizens who have not achieved permanent residence after five years, the CJEU first added flesh to the bones of European citizenship. In the Sala case from 1998 (C-85/96), the Court introduced Union citizenship as a fundamental status of member state nationals (Dougan, 2013, p. 133). This judicial vision of European citizenship was confirmed and extended in Grzelczyk (C-184/99) and Baumbast (C-413/99), among other cases. The Court stated that if a 'certain link' had been established before the five years of residence, the individual might enjoy the right to equal treatment under EU law, however left the definition of such a link open. Recently, the CJEU appears to have undertaken a judicial turn, embarking on a much more restrictive line of interpretation. With Dano (C-333/13), Alimanovic (C-67/14), Garcia-Nieto (C-299/14) and Commission vs UK (C-308/14) among others, we see a clear turn away from the previous judicial vision of European citizenship. In these cases, the Court refrained from basing its interpretations on the Union Citizenship wording of primary law and instead turned to the conditioned rights of secondary legislation as stated in the Residence Directive. Legal residence presupposes the right to equal treatment. Sufficient resources and not becoming an unreasonable burden thus become requirements for obtaining and maintaining the right to reside, and only those with legal residence have a right to equal treatment. However, we find no judicial clarification of when EU citizens fulfil the requirements. The legislative provisions are vaguely formulated and ambiguous which allows for discrepancies in implementation (Thym, 2015, p. 26). The case law of the Court could have clarified the meaning of primary and secondary law, but the judicial turn and the open character of these interpretations leave confusion, which again allows for arbitrary applications on the ground.

Reading into the provisions of secondary law and subsequent judicial interpretations hereof, it stands out that key concepts remain rather open or underspecified. Such underspecified concepts or provisions in particular count the concept of worker and the social protection hereunder, the social rights of economically inactive EU citizens who have not yet achieved permanent residence, in particular what constitutes sufficient resources and when an EU citizen can be considered an 'unreasonable burden' to the social assistance system of a hosting Member State. The legal uncertainty ultimately gives wider room for interpretation at the national level and in the practical implementation process. Whether this leads to variation on the ground or whether SLBs receive and follow domestic signals will be addressed in the subsequent empirical part of the paper.

\section{EMPIRICAL ANALYSIS}

\subsection{Case selection and data}

We trace street-level implementation of European case law on cross-border welfare in three country case studies, namely Denmark, Austria and France. We examine 1) how SLBs in the respective countries apply the concept of worker, and 2) the social rights of economically inactive EU citizens who have not yet achieved permanent residence, in particular what constitutes sufficient resources as well as 'unreasonable burden' when it comes to welfare access. The specific welfare benefit examined in the three cases was the social assistance scheme (Denmark: kontanthjolp; Austria: bedarfsorientierte Mindestsicherung, earlier: Sozialhilfe; France: revenu de solidarité active, earlier: revenu minimum d'insertion).

We selected Denmark, Austria and France as these countries differ on a number of explanatory factors that are well established in the literatures on EU compliance and 
comparative Europeanisation studies (see Table 1). The three Member States belong to different welfare models (Esping-Andersen, 1990), different 'worlds of compliance' (Falkner et al., 2005) and they differ with regard to centralised or federal structures as well as their general acceptance or reluctance towards supranational judicial review (Wind, 2010). Not least, these institutional factors lead us to expect different outcomes in the street-level implementation of EU law.

Table 1: Institutional Differences across Country Cases

\begin{tabular}{|c|c|c|c|}
\hline & Denmark & Austria & France \\
\hline Welfare model & $\begin{array}{l}\text { Social-democratic, } \\
\text { universal }\end{array}$ & $\begin{array}{l}\text { Conservative, social } \\
\text { insurance based }\end{array}$ & $\begin{array}{l}\text { Conservative, social } \\
\text { insurance based }\end{array}$ \\
\hline $\begin{array}{l}\text { Worlds of } \\
\text { compliance }\end{array}$ & World of compliance & $\begin{array}{l}\text { World of domestic } \\
\text { politics }\end{array}$ & World of neglect \\
\hline $\begin{array}{l}\text { Administrative } \\
\text { structure }\end{array}$ & $\begin{array}{l}\text { Unitary state, but } \\
\text { with considerable } \\
\text { decentralisation }\end{array}$ & Federal state & Unitary state \\
\hline Judicial review & Weak & Strong & Weak \\
\hline
\end{tabular}

We conducted in total 62 semi-structured interviews in Denmark, Austria and France, mostly with SLBs or other local employees close to the case-handling process and their superiors. Together, they decide upon social assistance claims and the residence rights of EU migrants (see Table 2). Two sets of interview questions were particularly relevant for the following analysis. Firstly, we asked case workers how they applied the EU legal principles and provisions identified above in practice, e.g. the concept of worker or the threshold of sufficient resources. Secondly, we asked to what extent they kept track of the evolving case law of the CJEU themselves and what other instructions or guidance, they received on how to apply these EU legal principles. Additional interviews were conducted with rights advocacy groups. We triangulated our interview data with systematic and longitudinal tracing of policy documents, legislative developments, judicial interpretation and, wherever accessible, internal guidelines on the application of EU law in the context of EU migrants' access to welfare benefits. This moreover enabled tracing of respectively political, administrative and judicial signalling in each of the three country cases, as illustrated in Table 2. 
Table 2: Data Collection

\begin{tabular}{|c|c|c|c|}
\hline & Denmark & Austria & France \\
\hline $\begin{array}{l}\text { Political } \\
\text { signalling }\end{array}$ & $\begin{array}{l}\text { Legislative developments } \\
\text { via national legislative } \\
\text { database } \\
\text { (' } w w w . r e t s i n f o r m a t i o n . d k ' \text { ') } \\
\text { and respondents, debates in } \\
\text { Parliament and policy } \\
\text { programmes via } \\
\text { parliamentary website } \\
\text { ('ft.dk/da/dokumenter') }\end{array}$ & $\begin{array}{l}\text { Legislative developments } \\
\text { via national legislative } \\
\text { database } \\
\text { (https://www.ris.bka.gv.at) } \\
\text { and respondents, debates in } \\
\text { Parliament and policy } \\
\text { programmes via } \\
\text { parliamentary website } \\
\text { (https://www.parlament.gv. } \\
\text { at) }\end{array}$ & $\begin{array}{l}\text { Legislative developments } \\
\text { via national legislative } \\
\text { database } \\
\text { ( } \underline{\text { https://www.legifrance.go }} \\
\underline{u v . f r} \text { ) and respondents, } \\
\text { debates in Parliament and } \\
\text { policy programmes via } \\
\text { parliamentary website } \\
\text { (http://www2.assemblee- } \\
\text { nationale.fr/documents- } \\
\text { parlementaires) }\end{array}$ \\
\hline $\begin{array}{l}\text { Administr } \\
\text { ative } \\
\text { signalling }\end{array}$ & $\begin{array}{l}\text { Ministerial legislative } \\
\text { guidelines via national } \\
\text { legislative database } \\
\text { ('retsinformation.dk'), } \\
\text { caseworker guidelines } \\
\text { when available, course } \\
\text { material when accessible, } \\
\text { ministerial orders via } \\
\text { respondents }\end{array}$ & $\begin{array}{l}\text { Guidelines of district } \\
\text { administrations and regions } \\
\text { (the latter in the case of } \\
\text { Vienna) if applicable, } \\
\text { manual of the Ministry of } \\
\text { the Interior, orders via } \\
\text { respondents }\end{array}$ & $\begin{array}{l}\text { Circulars and information } \\
\text { notes of the Ministry of } \\
\text { Social Affairs and of the } \\
\text { head office of the agency } \\
\text { competent for minimum } \\
\text { resources (Caisse nationale } \\
\text { des allocations familiales) }\end{array}$ \\
\hline $\begin{array}{l}\text { Judicial } \\
\text { signalling }\end{array}$ & $\begin{array}{l}\text { National court cases via } \\
\text { national judicial database } \\
\text { ('Ugeskrift for Retsveesen'), } \\
\text { administrative principle } \\
\text { rulings via 'Ankestyrelsen' }\end{array}$ & $\begin{array}{l}\text { National court cases via } \\
\text { national judicial database } \\
\text { (https://www.ris.bka.gv.at/J } \\
\text { udikatur) }\end{array}$ & $\begin{array}{l}\text { National court cases via } \\
\text { national judicial database } \\
\text { (https://www.legifrance.go } \\
\text { uv.fr/Sites/Juridictions); } \\
\text { social rulings via bulletins } \\
\text { on social jurisprudence } \\
\text { (http://solidarites- } \\
\text { sante.gouv.fr/ministere/doc } \\
\text { umentation-et- } \\
\text { publications- } \\
\text { officielles/bulletins- } \\
\text { officiels/article/cahiers-de- } \\
\text { jurisprudence-de-l-aide- } \\
\text { sociale). }\end{array}$ \\
\hline $\begin{array}{l}\text { Frontline } \\
\text { practices }\end{array}$ & $\begin{array}{l}\text { Interviews with } 11 \\
\text { respondents } \\
\text { (municipalities, Ministry of } \\
\text { Employment, residence } \\
\text { permit agency, immigration } \\
\text { services) }\end{array}$ & $\begin{array}{l}\text { Interviews with } 37^{1} \\
\text { respondents (district } \\
\text { administrations, regional } \\
\text { administrations, Ministry } \\
\text { of Social Affairs, Ministry } \\
\text { of the Interior, rights } \\
\text { advocacy groups) }\end{array}$ & $\begin{array}{l}\text { Interviews with } 14 \\
\text { respondents (district } \\
\text { administrations, local } \\
\text { branches of the agency } \\
\text { competent for minimum } \\
\text { resources, head office of } \\
\text { the relevant agency, } \\
\text { Ministry of Social Affairs, } \\
\text { Ministry of the Interior, } \\
\text { rights advocacy groups) }\end{array}$ \\
\hline
\end{tabular}

\footnotetext{
${ }^{1}$ More interviews were conducted for Austria because of federalism where social assistance is within the competence of the regions.
} 
In the remainder of this article, we present our findings on SLBs' case-handling for our three country cases. The engagement with the bureaucratic frontline reveals a predominantly restrictive administrative practice across all three Member States caused by domestic signalling.

\subsection{Denmark}

When an EU citizen applies for Danish social assistance, the decision is made by street-level bureaucrats in the local municipality. Despite belonging to the Social Democratic, universal welfare model with 'decommodified' social rights (Esping-Andersen, 1990), main access to Danish welfare as an EU citizen depends on whether the person qualifies as a 'worker' under European law. This makes the frontline decision on the applicant's 'worker status' essential for the right to equal treatment. Economically inactive EU citizens are on the other hand in most cases excluded from the social assistance scheme. The Danish case shows that domestic signalling is of high importance, especially when street-level bureaucrats are left without sufficient guidance on the complex and contradictory European free movement rules.

At first sight, the Danish interpretation of the worker concept seems clear. In response to CJEU case law, one obtains worker status in Denmark upon 10-12 working hours per week over at least 10 weeks. $^{2}$ This message is remarkably well known among frontline workers. Administrative signalling has thus clearly communicated this through websites and guidelines, yet ignored how complex the decision typically is in in practice. Especially fluctuating working hours and the level of salary cause frontline trouble. Both factors are often relevant in EU citizens' cases as they are overrepresented in precarious employment relations in Denmark. ${ }^{3}$ In result, municipalities are left without guidance and in some cases even establish restrictive local rules (Interview, 28 March 2017). Given the strong political and administrative signalling described below, frontlines often opt for the safer option of rejecting borderline applications.

Up until recently, frontline bureaucrats would send a 'control case' to the residence permit authority, the 'State Administration', when in doubt whether an EU citizen was eligible to social assistance (interview, 7 September 2015). In March 2014, however, a clear political message was sent. A policy package launched by the Social Democratic coalition government instructed municipalities to refer all EU applicants without permanent residence for an additional checkup and not only those deemed to be borderline cases. ${ }^{4}$ In this way, the State Administration obtains stricter control with frontline decisions. Moreover, the authority has in this period become increasingly restrictive in their daily interpretations (interview, 27 March 2017). One example is concerning the sanctions that jobcentres issue if beneficiaries do not fulfil their obligations. Municipalities are now asked to refer EU citizens who have been subject to such sanctions as this might be sufficient ground to terminate their legal residence (interview, 27 and 28 March 2017). Meantime, the State Administration has become more active in disseminating the national interpretation of the rules through intensified frequency of visits and training sessions among municipalities (interview, 28 March 2017).

Municipalities have in general become more restrictive, increasingly often refusing social assistance with reference to lack of legal residence (interview, 28 September 2015). In our interviews, this is explained by more restrictive administrative signalling from the State Administration but also from the national political level. Political signalling travels from the superiors and into the local administration:

"It is a political signalling from the top. And we have to follow it if we want to keep our job. It [signalling] has simply become more restrictive. Also with the same law. It is the

\footnotetext{
${ }^{2}$ Danish Immigration Service, administrative instructions, November 2015.

${ }^{3}$ Danish Agency for Labour Market and Recruitment 28 August 2018 J.nr. 18/11780.

${ }^{4}$ Ministry of Employment, March 2014, ' Forslag 1: Øget kontrol af kontanthjcelpsmodtageres arbejdstagerstatus'.
} 
interpretation of the law which has become more restrictive." (Interview, 27 March 2017).

Both political and administrative signalling thus clearly shows through in the Danish case.

Judicial signalling has on the other hand remained rather low. Between 2002 and 2017, no Danish Court case considered EU citizens' right to social assistance. The only judicial interpretation made is through quasi-judicial redress in the administrative recourse system. In this period, only seven such 'principle' rulings concerned EU citizens' right to social assistance and in only four cases the benefit was granted (Martinsen, Pons Rotger, \& Thierry, 2018). Judicial superiors have thus not signalled importance of EU law to SLBs in the Danish case. Subsequently, caseworkers typically do not consider EU legislation or CJEU jurisprudence directly but look into national (case) law and guidelines for instructions. The impact of CJEU jurisprudence on the social rights of EU citizens thus depends on changes of national legislation, guidelines, legal minutes issued by the Ministry of Justice or domestic court cases. At times, CJEU case law is not even heard of at the municipal level (interviews, 27 and 28 March 2017).

Before the Dano and Alimanovic cases, there was a concern that the jurisprudence of the Court would impair the restrictive Danish practice on EU citizens' right to social assistance. The Danish government therefore submitted observations in both cases. The government welcomed the restrictive approach in the judgements, interpreting them to confirm the restrictive Danish practice and to spare the government from changing Danish legislation or ministerial guidelines. ${ }^{5}$ In response to the case Commission vs the UK (C-308/14), the Minister of Employment signals satisfaction with the judicial turn:

"Even though the judgment does not have a concrete impact for Denmark, I find it positive that the CJEU continues the line from other, recent judgements. The CJEU has laid down that even though the requirement on legal residence indirectly discriminates against EU citizens, the requirement is justified to protect public finances" (answer to the Parliament's Committee on Integration, parliamentary question no. 718, 24. June 2016).

Economically inactive EU citizens without permanent residence are in most cases excluded from Danish social assistance. They can acquire legal residence if they have sufficient resources'. Administrative signalling in this respect is clear and restrictive. The competent national agency explicitly states that sufficient resources are assessed on an individual basis, however generally amounting to the level of a social assistance benefit plus housing benefit. ${ }^{6}$ If an EU citizen with legal residence on these grounds loses his/her sufficient means and applies for social assistance, the caseworker will report to the State Administration who subsequently may terminate the right to reside. In such situations, the caseworker will decide upon an individual assessment whether to grant social assistance temporarily. This, however, will be regarded as a compromising factor if $\mathrm{s} /$ he later applies for permanent residence in Denmark (interview, 28 September 2015; see also the official website 'New to Denmark' on public benefits).

In sum, we see Danish frontline administration of EU law as becoming uniformly more restrictive because of more restrictive administrative and political signalling. When coping with the legal ambiguity and underspecified concepts of EU law, caseworkers turn to the political and administrative signalling for guidance. The impact of CJEU case law is thus in part conditioned by national actors, and mitigated by the way they read, understand and communicate jurisprudence to the frontline. In result, municipalities will typically not consider

\footnotetext{
${ }^{5}$ See European Affairs Committee, parliamentary questions no. 28, 5. December 2014 and no. 3, 12. October 2015 as well as the Parliament's Committee on Integration, parliamentary question no. 567, 26. May 2016

${ }^{6}$ See the State Administration guidelines at http://www.statsforvaltningen.dk/site.aspx?p=9202, accessed 8. February 2019.
} 
Court jurisprudence themselves but rely on national level actors for a legal translation. The national level refused the impact of the earlier more expansive jurisprudence but welcomed the later restrictive turn of the CJEU, which instead corresponded with the established practice.

\subsection{Austria}

In Austria, EU migrants' claims for social assistance are decided by caseworkers in the social units of district administrations who apply the relevant regional legislation on social assistance. In addition, caseworkers in the immigration units of district administrations often play a crucial role by controlling the legal residence of EU citizens, which is a precondition for accessing benefits. As in the Danish case, Austrian frontline bureaucrats have followed domestic signals to restrict EU citizens' access to welfare benefits over the last decade. This restrictive trend is pronounced with regard to economically inactive EU citizens without permanent residence, and also with regard to workers as long as domestic courts do not challenge this by signalling an expansive interpretation of the rules.

The EU concept of worker is far from clear for Austrian frontline bureaucrats who typically do not consider EU law directly. Their basic instruments are Austrian law and orders, which they expect to be EU compliant. EU citizens were typically automatically treated on equal terms with Austrians up until 2006 where a legal reform changed the practices. Political signals here pointed towards restriction. Austria's original transposition of Directive 2004/38 in 2006 and later reforms explicitly aimed at restricting welfare access of EU citizens. With the 2006 reform, EU citizens are now obliged to obtain a registration certificate documenting - and not establishing - legal residence. Subsequently, welfare authorities are instructed to restrict access to social assistance to EU citizens who can show a registration certificate.

In response to administrative signals, immigration authorities, who issue the certificate, have furthermore become more restrictive when determining legal residence and deciding upon the registration certificate. This turn implies that immigration authorities are now instructed to require that the employment fulfils the definition under national insurance provisions and hence exceed a low income threshold (€438,05 in 2018) ${ }^{7}$. Some immigration authorities demand the level of the salary to correspond with the social assistance level. In contrast to the Danish case, administrative signalling occurs more ad hoc and hardly coordinated at the federal level (interview, 1 September 2016), not least since social assistance is regional competence. For example, when asked about her receptiveness to CJEU jurisprudence, one caseworker explains that she had received a print-out of the Dano judgment from her regional manager without any specific instructions but the general advice of using it to be 'restrictive' whenever possible (interview, 29 October 2015).

We identify few examples of more generous practice prompted by expansive local judicial signalling. In some larger cities, welfare authorities have started to assess themselves whether a person is a worker and no longer rely on the registration certificate. Two respondents explain that they apply a 'Genc threshold' of 5.5 hours (Genc, C-14/09) to identify 'genuine and effective work'. These local managers are aware that this is the most generous precedent but argue that any other approach would hardly be manageable in practice nor resilient against legal challenges (interview, 3 October 2016). Indeed, some domestic courts referred to EU law and insisted on an expansive interpretation. For instance, the administrative court of Vienna considered seven hours with a salary of 100 euro per week within the definition of work. ${ }^{8}$ Altogether, restrictive political and administrative signalling clearly show through in the Austrian case, leading to a restrictive administration of the concept of 'worker' on the ground. This is, however, counteracted in some cities by more expansive judicial signalling.

\footnotetext{
${ }^{7}$ Cf. the website of the Bundeskanzleramt at https://www.help.gv.at/Portal.Node/hlpd/public/content/99/Seite.990119.html, accessed 13 November 2018.

${ }^{8}$ Administrative court of Vienna, judgment of 5 October 2015, VGW-141/023/9654/2015.
} 
Austrian administrative practice towards economically inactive EU citizens has also become increasingly restrictive over the last decade. Consequently, similar to the Danish situation, EU citizens without worker status are now effectively excluded from social assistance and are threatened to lose their residence right if they apply for social benefits. In order to restrict their access to welfare, Austrian frontline bureaucrats raised the 'sufficient resources' threshold. Despite considerable cross-regional legislative variation regarding social assistance (Windisch-Graetz, 2014), the practice is uniform towards restrictive rule application.

In most Austrian regions, economically inactive EU citizens with legal residence may in principle - qualify for social assistance. In practice, however, it has become almost impossible for them to acquire the registration certificate and claim welfare benefits at the same time. As elaborated earlier, it has become increasingly difficult to receive the certificate. In the case of economically inactive EU citizens, immigration authorities have become more reluctant to take saving deposits into account when assessing 'sufficient resources' (interview, 29 October 2015). Rather, EU citizens must document some sort of regular income and, even though EU law prohibits a fixed threshold to determine 'sufficient resources', the guidelines from the Ministry of Interior suggest caseworkers to apply a threshold of to the regional level of social assistance (interview, 28 January 2016). In 2010, Austria further restricted practice by revising the residence legislation. In result, receipt of a supplementary pension is now excluded when calculating sufficient resources (Felten, 2012). As an example of clear administrative signalling, the Ministry of Social Affairs explicitly finds it 'problematic' if economically inactive EU citizens apply for social assistance. Receipt of benefits may, it is stated, terminate their right to reside as the application alone may suggest that the EU citizen is an 'unreasonable burden' (Bundesministerium für Arbeit Soziales und Konsumentenschutz, 2014, p. 11, 14). When granting social assistance, welfare authorities should thus inform the immigration authority.

Some Austrian welfare authorities have started to assess legal residence themselves independently from the registration certificate whenever EU citizens apply for social assistance and reject the benefit request of economically inactive persons for not having sufficient resources (interview, 3 October 2016). Since 2010, the city of Vienna has excluded economically inactive EU citizens from social assistance already at the legislative level. This was confirmed by the administrative court of Vienna and now only migrant workers qualify for social assistance in this region. ${ }^{9}$ While this automatic exclusion raised legal doubts in the past (Windisch-Graetz, 2014), the CJEU's recent Dano and Alimanovic rulings are interpreted as a confirmation of Vienna's restrictive approach (interview, 1 September 2016). Moreover, in order to qualify for permanent residency in this region, five years of residence cannot stand alone but requires five years of documented employment and comprehensive health insurance (interview, 26 January 2016). Also this practice is highly restrictive and even goes further than the Danish practice where consumption of welfare is merely regarded as a compromising factor in the overall assessment.

The reform of residence legislation from 2010 was challenged in court leading to the Brey judgment in which the CJEU emphasized the criterion of an unreasonable burden and required decisions based on individual assessments. In its interpretation of the ruling, the Austrian Supreme Court ${ }^{10}$ basically considered the registration certificate as constitutive. This interpretation was followed by some regional courts holding that EU citizens were entitled to social assistance as long as the registration certificate was not revoked. ${ }^{11}$ In 2016, the Austrian Supreme Court partly reversed its own Brey jurisprudence and endorsed the ruling of a lower court instead, which argued that the CJEU's Dano and Alimanovic rulings had corrected its

\footnotetext{
${ }^{9}$ For instance: administrative court of Vienna, judgment of 15 January 2014.

${ }^{10}$ Austrian Supreme Court (Oberster Gerichtshof), judgment of 17 December 2013, 10ObS152/13w.

${ }^{11}$ For instance: administrative court of Salzburg, judgment of 22 July 2015, LVwG-9/160/19-2015.
} 
earlier Brey decision in a more restrictive direction ${ }^{12}$, thus no longer pushing for an expansive interpretation of EU law. This line was taken up by lower courts. ${ }^{13}$

In sum, despite the federal system Austrian bureaucrats have in recent years changed practice towards a predominantly uniform, restrictive interpretation both concerning economically inactive EU citizens and workers. The change is found to be caused by restrictive political and administrative signalling and to some extent judicial signalling. In some regions, the worker definition is, however, administered generously due to expansive judicial signalling. CJEU case law has been interpreted through this restrictive lens of domestic signals and only with some exceptions result in a restrictive trend across Austria.

\subsection{France}

In France, EU citizens' applications for social assistance are administered by caseworkers in either the social units of district administrations or the district offices of a national agency. Also caseworkers in immigration authorities are involved in the assessment if the EU citizen applies for an - optional - registration certificate. The certificate allows for welfare access with the social authorities. As in the Austrian and Danish case, French frontline bureaucrats have listened to domestic signals of superiors within the last decade and restricted EU citizens' access to social assistance. Both eligibility of economically inactive EU citizens without permanent residence and the concept of 'worker' are now subject to narrow interpretation.

French interpretation of worker status and thus access to social assistance is administered under the Ministry of Social Affairs and Health and the head office of the agency competent for family benefits, the National Family Benefits Fund (Caisse nationale des allocations familiales, CNAF). Circulars of the two institutions from 2005 only included the ambiguous Court formulations that employment should be 'genuine and effective'. ${ }^{14}$ In 2008 and 2009, two new pieces of guidelines were introduced and established a clear but restrictive definition of the 'worker' concept. ${ }^{15}$ The new guidelines identify two alternative ways of assessment: Caseworkers can either ask health insurance institutions whether the person is insured as a worker, or, secondly, they examine themselves whether the person within 30 consecutive days has worked at least 60 hours or had a salary at least 60 times higher than the minimum hourly wage ${ }^{16}$, i.e. at least 588 euro in 2018 (interview, 31 August 2016). Apart from providing legal certainty, these efforts are expected to harmonize the practices throughout France (interview, 16 June and 21 July 2017).

Caseworkers quickly adopted these clear definitions of the circulars into their practice. Some local welfare authorities opt for the first way and consult the health insurance institution to find whether the person is insured as a worker (interview, 29 July and 24 August \& 31 August 2016). Other local welfare authorities follow the second procedure and examine the conditions as laid down in the instruments (interview, 8 and 18 July and 10 August and 16 September 2016). Ultimately, the new practice makes it more difficult to obtain worker status and excludes EU citizens in more precarious work from social protection. This group subsequently loses the possibility to top up their income with social assistance. Administrative signalling of superior actors thus clearly shows through in the French case regarding the definition of worker.

Economically inactive EU citizens without permanent residence have, in large, been excluded from social assistance in practice. Although EU citizens since 2003 have been spared the requirement of a registration certificate, ${ }^{17}$ they are still advised to apply for the document

\footnotetext{
${ }^{12}$ Austrian Supreme Court, judgment of 10 May 2016, 10 ObS 15/16b.

${ }^{13}$ For instance: administrative court of Salzburg, judgment of 16 November 2016, 405-9/123/1/12-2016.

${ }^{14}$ Ministère de l'Emploi, du Travail et de la Cohésion Sociale, information note NoDGAS/1C/2005/165 du 24 mars 2005 , p. 4.

${ }^{15}$ Caisse Nationale des Allocations Familiales, circular n ${ }^{\circ}$ 2008-024; Caisse Nationale des Allocations Familiales, circular C $\mathrm{n}^{\circ}$ 2009-022, p. 10.

${ }^{16}$ Salaire minimum interprofessionnel de croissance, SMIC.

${ }^{17}$ Caisse Nationale des Allocations Familiales, circular n 2003-015,
} 
as it guarantees welfare access. ${ }^{18}$ In 2008-2009, clear criteria of eligibility to social assistance were eventually introduced. In order to be lawfully residing in France as an economically inactive EU citizen and therefore entitled to social assistance, EU citizens are required to have health insurance and 'sufficient resources'. The latter should equal at least six months of the standard amount of social assistance. ${ }^{19}$ Even though economically inactive EU citizens in France, unlike in Denmark and Austria, thus may be eligible for social assistance they are in practice faced with a high threshold.

Similar to the administration of EU workers, frontline bureaucrats typically apply these clear national rules in practice. EU law, on the other hand, play an insignificant role. In the rare case that economically inactive EU citizens has a registration certificate, social authorities grant assistance for the period of time equivalent to the duration of the certificate. The duration of the validity is defined upon the EU citizen's resources when applying, i.e. more resources prompt slower expiration of the certificate (interview, 8 and 13 and 29 July and 10 August 2016). In case economically inactive EU citizens do not have a registration certificate, social authorities examine themselves whether the claimants has health insurance and sufficient resources. With regard to the latter, social authorities follow the definition as laid down in the circulars mentioned above (interviews, 8, 18 and 29 July, 31 August \& 28 September). As a consequence, only if EU citizens have the amount of money which is necessary for sufficient resources as assets or properties, could they qualify for social assistance as only a share of these means ${ }^{20}$ was included when calculating the entitlement to social assistance. ${ }^{21}$ More expansive CJEU rulings such as Bidar or Grzelczyk have thus not played a role and, paradoxically, only richer EU citizens are eligible for social assistance. The impact of CJEU jurisprudence at the street level has thus been thwarted via national guidelines. Similar to the Danish and Austrian cases, recent case law such as Dano is perceived to confirm the restrictive interpretation of EU law by French authorities (interview, 16 June 2017).

These restrictive practices and rules are not challenged but rather confirmed by domestic courts. Courts signal that authorities can apply the sole condition of lawful residence demonstrated via sufficient resources and a health insurance. Namely, 'the access to social assistance benefits depends upon a right of residence and consequently the criteria for a right of residence; $[\ldots]$ the principle of non-discrimination does not preclude differences in treatment if it is justified for objective reasons'.22

In sum, French frontline practices have uniformly become more restrictive in response to strong administrative and judicial signalling since 2008-2009. Both the definition of worker and the eligibility criteria of economically inactive EU citizens have become subject to restrictive interpretation.

\section{CONCLUSION}

Frontline bureaucrats administer EU rules and jurisprudence in practice. They consider the applications of EU citizens on welfare benefits and in doing so decide on eligibility, worker status and potentially the right to reside. Their concrete case handling determines the outcomes of EU law. In making their decisions, they interpret key concepts such as who is a worker, what counts as "sufficient resources" and when to perceive an applicant an "unreasonable burden" when it comes to welfare access.

\footnotetext{
${ }^{18}$ Caisse Nationale des Allocations Familiales, circular n²006-017.

${ }^{19}$ Caisse Nationale des Allocations Familiales, circular $\mathrm{n}^{\circ}$ 2008-024; Caisse Nationale des Allocations Familiales, circular C $\mathrm{n}^{\circ}$ 2009-022, pp. 8, 14, 23.

${ }^{20}$ Assets: $3 \%$ per year; real estate in form of buildings: $50 \%$ per year; properties in form of undeveloped land: $80 \%$ per year.

${ }^{21}$ Caisse Nationale des Allocations Familiales, circular C - n 2012-014, p. RSA 48.

${ }^{22}$ Administrative court of appeal of Paris, judgment of 20 October 2011, 10PA05222.
} 
In principle, EU binding legislation and CJEU decisions should instruct frontline bureaucracy. However, rules on free movement of persons and cross-border welfare imply legal ambiguity and underspecified key provisions. In this world of legal complexity, the CJEU is often called upon to interpret and guide national implementation. But as we have seen, legal interpretations deal with individual situations, which are not easily applied to a larger set of cases. Despite the rich body of CJEU cases, key concepts thus continue to be underspecified and rather open. Even with many years of detailing the worker concept, considerable discretion remains. On top of this, more recent CJEU jurisprudence marks a judicial turn. Social rights of non-active EU citizens are now increasingly subjected to the conditions as set out in secondary legislation. Here, 'sufficient resources' and 'unreasonable burden' are key administrative demarcations upon which EU citizens can be denied not only social benefits but also the right to reside.

Our comparative analysis demonstrates that when SLBs are to make decision on basis of rather opaque and ambiguous rules, they turn to their domestic superiors for instructions. In this way, signalling from national levels above comes to guide and influence decisions on the ground. The signals sent from domestic superiors are picked up at the frontline. In all three cases examined, we saw political and administrative superiors effectively signalling a more restrictive line towards EU migrants and their cross-border access to welfare benefits. At the same time, judicial signals were largely absent or joined in on the restrictive interpretation of EU rules and rights. In our case, domestic courts typically did not serve as leverage for extending migrants' rights in national case-handling.

Hence, through various forms of domestic signalling, even different Member States tended to have a uniform (and restrictive) rather than highly varied frontline practice of European free movement rules. By exploring how frontline bureaucracy administers complex EU rules in day-to-day case-handling, our study joins in on the emerging field of the practical implementation of EU law. We come, however, to a rather different conclusion: while others have found that frontline practices fragment EU law, we find that such are often subject to strong domestic signalling which influence outcomes. In our case, politicisation of free movement and cross border welfare, increasingly negatively framed in public debates as 'welfare tourism', appear to be a relevant background factor for the restrictive signalling across member states. With politicisation the issue has become more visible and important in various member states (Blauberger et al., 2018 ).

Our study contributes to EU implementation studies by at least three main findings. First, it shows that domestic signals on the importance and meaning of EU law influence frontline bureaucrats in their case-handling. It matters how domestic superiors perceive and prioritise EU law. Secondly, it demonstrates that the politics of such signals are especially important. The political and administrative superiors were effective communicators of their preferred understanding of EU law, which was largely unchallenged in domestic courts. This finding points out that there is considerable room for politics in EU implementation processes and that SLBs are responsive hereto. Thirdly, our findings demonstrated that CJEU case law is not necessarily attended to on the ground. At the frontline of rule application, CJEU case-law appears less powerful and directional for bureaucratic routines and decision-making than oftentimes assumed. SLBs do not pay much direct attention to individual CJEU decisions, which consequently remain obscure and rather remote from the day-to-day application.

To conclude, in a world of legal complexity, the signalling of domestic superiors come to guide the application of law. In that signalling process, politics play a prominent role, whereas European case law proved less influential. Despite the many differences between Denmark, Austria and France, signalling came to guide case handling at the bureaucratic frontline towards the same restrictive trend. Meanwhile, rules from Brussels and judicial decisions from Luxembourg remain rather distant and opaque. 


\section{REFERENCES}

Banks, J. S., \& Weingast, B. R. (1992). The political control of bureaucracies under asymmetric information. American Journal of Political Science, 509-524.

Bardach, E. (1977). The Implementation Game. What Happens After a Bill Becomes a Law. Cambridge, MA: MIT Press.

Baum, L. (1976). Implementation of Judicial Decisions. An Organizational Analysis. American Politics Quarterly.

Blauberger, M. (2013). With Luxembourg in mind... the remaking of national policies in the face of ECJ jurisprudence. In S. K. Schmidt \& R. D. Kelemen (Eds.), The Power of the European Court of Justice (pp. 109-126). London/New York: Routledge.

Blauberger, M., Heindlmaier, A., Kramer, D., Martinsen, D. S., Thierry, J. S., Schenk, A., \& Werner, B. (2018). ECJ judges read the morning papers. Explaining the turnaround of European citizenship jurisprudence. Journal of European Public Policy, 25(10), 1422-1441.

Blauberger, M., \& Schmidt, S. K. (2017). Free Movement, the Welfare State, and the European Union's Over-Constitutionalization: Administrating Contradictions. Public Administration, 95(2), 437449.

Brehm, J. O., \& Gates, S. (1999). Working, shirking, and sabotage: Bureaucratic response to a democratic public: University of Michigan Press.

Bundesministerium für Arbeit Soziales und Konsumentenschutz. (2014). Bedarfsorientierte Mindestsicherung. Fragen und Antworten. Fakten statt Mythen. Vienna: Bundesministerium für Arbeit, Soziales und Konsumentenschutz.

Canon, B. C. (1991). Courts and Policy: Compliance, Implementation, and Impact. In J. G. Gates \& C. A. Johnson (Eds.), American Courts: A Critical Assessment (pp. 435-466). Washington D.C.: Congressional Quarterly Press.

Conant, L. J. (2002). Justice Contained, Law and Politics in the European Union. Ithaca: Cornell University Press.

Davies, G. (2012). Activism Relocated. The Self-Restraint of the European Court of Justice in its National Context. Journal of European Public Policy, 19(1), 76-91.

Dörrenbächer, N. (2017). Europe at the frontline: analysing street-level motivations for the use of European Union migration law. Journal of European Public Policy, 1-20.

Dörrenbächer, N., \& Mastenbroek, E. (2017). Passing the buck? Analyzing the delegation of discretion after transposition of European Union law. Regulation \& Governance.

Dougan, M. (2013). The Bubble that Burst: Exploring the Legitimacy of the Case Law on the Free Movement of Union Citizens. Judging Europes's Judges. The Legitimacy of the Case Law of the European Court of Justice, Oxford: Hart, 132.

Esping-Andersen, G. (1990). The three worlds of welfare capitalism: John Wiley \& Sons.

Falkner, G., Treib, O., Hartlapp, M., \& Leiber, S. (2005). Complying with Europe: EU Harmonisation and Soft Law in the Member States. Cambridge: Cambridge University Press.

Felten, E. (2012). Sozialtourismus in der EU. Möglichkeiten und Grenzen der Optimierung von Sozialleistungen nach dem Unionsrecht. Das Recht der Arbeit, 2012(5), 461-472.

Hofmann, A. (2018). Resistance against the Court of Justice of the European Union. International Journal of Law in Context, 14(2), 258-274. doi:10.1017/S174455231800006X

Levine, J. P. (1970). Methodological Concerns in Studying Supreme Court Efficacy. Law \& Society Review, 4(4), 583-612.

Lipsky. (1980). Street-Level Bureaucracy: The Dilemmas of Individuals in the Public Service. New York: Sage.

Martinsen, D. S. (2015). An Ever More Powerful Court? The Political Constraints of Legal Integration in the European Union. Oxford: Oxford University Press.

Martinsen, D. S., Pons Rotger, G., \& Thierry, J. S. (2018). Free movement of people and cross-border welfare in the European Union: Dynamic rules, limited outcomes. Journal of European Social Policy, 0958928718767300.

May, P. J., \& Winter, S. C. (2007). Politicians, Managers, and Street-Level Bureaucrats: Influences on Policy Implementation. Journal of Public Administration Research and Theory, 19(3), 453-476.

May, P. J., \& Winter, S. C. (2009). Politicians, managers, and street-level bureaucrats: Influences on policy implementation. Journal of Public Administration Research and Theory, 19(3), 453-476. 
Steunenberg, B., \& Toshkov, D. (2009). Comparing Transposition in the 27 Member States of the EU: the Impact of Discretion and Legal Fit. Journal of European Public Policy, 17(7), 951-970.

Thomann, E., \& Sager, F. (2017a). Moving beyond Legal Compliance: Innovative Approaches to EU Multilevel Implementation. Journal of European Public Policy.

Thomann, E., \& Sager, F. (2017b). Moving beyond legal compliance: innovative approaches to EU multilevel implementation. Journal of European Public Policy, 24(9), 1253-1268.

Thym, D. (2015). The elusive limits of solidarity: Residence rights of and social benefits for economically inactive Union citizens. Common Market Law Review, 52(1), 17-50.

Treib, O. (2014). Implementing and Complying with EU Governance Outputs. Living Reviews in European Governance, 9(1), 1-47.

Tummers, L. L. G., Bekkers, V., Vink, E., \& Musheno, M. (2015). Coping during Public Service Delivery: A Conceptualization and Systematic Review of the Literature. Journal of Public Administration Research and Theory, 25(4), 1099-1126.

Versluis, E. (2007a). Even rules, uneven practices: Opening the 'black box'of EU law in action. West European Politics, 30(1), 50-67.

Versluis, E. (2007b). Even Rules, Uneven Practives: Opening the 'Black Box' of EU Law in Action. West European Politics, 30(1), 50-67.

Wind, M. (2010). The Nordics, the EU and the Reluctance towards Supranational Judicial Review. Journal of Common Market Studies, 48(4), 1039-1063.

Windisch-Graetz, M. (2014). Zulässige Differenzierungen bei der Gewährung von Sozialleistungen. Zeitschrift für Arbeits- und Sozialrecht (ZAS), 33(4), 204-211.

Winter, S. C. (2012). Implementation. In G. B. Peters \& J. Pierre (Eds.), The SAGE Handbook of Public Administration.

Worsham, J., \& Gatrell, J. (2005). Multiple Principals, Multiple Signals: A Signaling Approach to Principal-Agent Relations. Policy Studies Journal, 33(3), 363-376.

Zhelyazkova, A., Kaya, C., \& Schrama, R. (2016). Decoupling practical and legal compliance: Analysis of member states' implementation of EU policy. European Journal of Political Research, 55(4), 827-846. 